\title{
Consideration of the Child's Image in Historical and Social Context in Modern Consumptive Society of Croatia and Bosnia and Herzegovina
}

\author{
Katarina Dadic ${ }^{*}$ \\ kdadic@hrstud.hr \\ https://orcid.org/0000-0002-3371-6297 \\ Ružica Bešlić Grbešić** \\ rgrbesic@hrstud.hr \\ https://orcid.org/0000-0002-7784-92780 \\ Vlatko Smiljanić*** \\ vsmiljanic@hrstud.hr \\ https://orcid.org/0000-0001-9835-0591
}

https://doi.org/10.31192/np.19.2.9

UDK / UDC: $37.013 .42-053.2(497.5+497.6) “ 20$ “

366:37.013.42-053.2

Prethodno priopćenje / Preliminary communication

Primljeno / Received:

7. prosinca 2020. / Dec 7, 2020

Prihvaćeno / Accepted:

17. veljače 2021. / Feb 17, 2021

The authors focus on a pluriperspective analysis of the image and status of children, with the emphasis on print media and consumer environment which is researched in the framework of special historical and social conditions. The research shows how the historical and social context of society in Croatia and Bosnia and Herzegovina is related to the image of the child in the relevant print media, scientific analyses and literature. Through this new thesis authors conclude that the present situation directly implies the need for proper care for the status of children and childhood within modern pedagogical science.

Key words: childhood, consumer environment, historical context, media, pedagogisation.

\footnotetext{
* Katarina Dadić, PhD, Assis. Prof., University of Zagreb, Faculty of Croatian Studies; Address: Borongajska cesta 83d, HR-10000 Zagreb, Croatia.

** Ružica Bešlić Grbešić, Master in Croatology and Sociology, University of Zagreb, Faculty of Croatian Studies; Adress: Borongajska cesta 83d, HR-10000 Zagreb, Croatia.

**** Vlatko Smiljanić, Master in Education of History, University of Zagreb, Research Institute of Faculty of Croatian Studies; Borongajska cesta 83i, HR-10000 Zagreb, Croatia.
} 


\section{Introduction}

The idea for this article came from the exchange and detailed analysis of research about pedagogical aspects of contemporary childhood in the consumer environment, based on stigmatisation and discrimination of children in print media in Croatia and Bosnia and Herzegovina. Combining these scientific researches gave a clearer picture of consumer and media stigmatization on child in pedagogy which authors will concisely present in this paper. It should be noted that the traces of transition and post-transition are still visible and pervasive in the researched countries.

Contemporary consumer environment on child clearly demonstrates, through the consumerist phenomena, that it seeks an active child as a subject of consumption (loyal or lifelong consumers) and a passive child as an object of consumption. Pedagogy as a science cannot agree with this »crude technological determinism «. As a result of new pluriperspective research of children and childhood the construct of the »competent child«, an active subject with his own needs, is dominantly present in pedagogical theory, but it has not become an integrative part of scientific researches in Croatia and Bosnia and Herzegovina. ${ }^{1}$

The paper relies on the work of $20^{\text {th }}$ century theoretician Karl Polanyi who, although originally an economic historian, never limited his observation of the discipline's subject to its conventional contents. Instead, Polanyi used a broader perspective of other social sciences in a way that creates a thesis about anthropologisation and sociologisation of economics. ${ }^{2}$ Along the lines of that, the authors dare to set the thesis about the pedagogisation of economics, socialism and relevant scientific analyses and the literature about the print media in Croatia and Bosnia and Herzegovina; this is the central intension of exploring in this work. Thus, this paper includes analysis and pluriperspective pedagogical theorizing of relevant scientific papers and literature in the field of history, sociology and communicology, which contextualize the image of the child in the print media in modern consumer society in Croatia and Bosnia and Herzegovina. In addition, the authors, as well as the authors of the cited papers, analysed the content of the most widely read newspapers in Croatia and Bosnia and Herzegovina which are Jutarnji list, Večernji list, Dnevni avaz and Oslobodenje where the image of the child was thematised. They want to

\footnotetext{
${ }^{1}$ Katarina DADIĆ, Pedagoški aspekti suvremenog djetinjstva u potrošačkom okruženju [Pedagogical Aspects of Modern Childhood in the Consumer Environment], PhD thesis, Zagreb, Filozofski fakultet, 2015, 2.

2 Cf. Ivan BURIĆ, Nacija zaduženih. Od komunističkog pakla do potrošačkog kapitalizma [Nation of indebtned. From communist hell to consumer capitalism], Zagreb, Jesenski i Turk, 2010; Karl POLANYI, Velika preobrazba. Politički i ekonomski izvori našeg vremena [The Great Transformation. Political and Economic Sources of Our Time], Zagreb, Jesenski i Turk, Hrvatsko sociološko društvo, 1999.
} 
emphasize what, in these notions on a child, is a pedagogical issue, what kind of image of the child is opposed to the pedagogical image of the child ${ }^{3}$, what is the pedagogical perspective ${ }^{4}$ which is followed by pedagogical paradigm. ${ }^{5} \mathrm{On}$ these bases, the active task of the pedagogue in the destigmatisation of children will be formed.

The main aim of this paper, which emerged from both research findings, is to present ideas and devise ways of pedagogical destigmatisation of children in the field of pedagogy in the view of its tendency towards an acting science. The emphasis will be put on the fields of pedagogy which can influence change through systematic research such as media pedagogy, critical pedagogy, comparative pedagogy, family pedagogy, andragogy etc. Also, the authors will stress the productive potential of all participants in the educational process. The long-term goal is to apply the results of this work to the neighbouring countries which have undergone similar historical and social processes as the two countries included in the research.

\section{Historical and Social Context in the Swing of Social Change on the Child}

The scope of the analysed research indicates specific post-socialist circumstances, the transition process and still visible process of post-transition. In both countries, the institutional legacy of communism, such as the massive and inefficient administration, bureaucratic access, overstatement and corruption, have also taken over the environment. Globally, poorly implemented privatization, inadequate Western assistance, or a template approach by international organizations, and the underdeveloped use of foreign investment in transition countries are other causes of under-transitional (un)success. ${ }^{6}$ The terms of tran-

${ }^{3}$ Cf. Slavica BAŠIĆ, Dijete (učenik) kao partner u odgoju. Kritičko razmatranje [Child (Student) as a Partner in Education: Critical Reflection], Odgojne znanosti, 11 (2009) 2, 27-44; Slavica BAŠIĆ, (New) Imagine of Child in Childhood Pedagogy, u: Dubravka MALEŠ (ur.), Nove paradigme ranog odgoja, Zagreb, Filozofski fakultet, 2011, 19-37; Yordanka DIMOVA, John Loughran, Developing a big picture understanding of reflection in pedagogical practice, Reflective practice, 10 (2009) 2, 205-217.

${ }^{4}$ Cf. Nicholas C. BURBULES, Forms of ideology-critique: a pedagogical perspective, Qualitative Studies in Education, 5 (1992) 1, 7-17; James C. McCROSKEY, Communication competence and performance: A research and pedagogical perspective, Communication education, 31 (1982) 1, 1-7; Marko PALEKČIĆ, The Pedagogical Theoretical Perspective, Zagreb, Erudita, 2015; Xavier ÚCAR, Exploring different perspectives of Social Pedagogy: towards a complex and integrated approach, Education Policy Analysis Archives, 21 (2013) 36, 1-19.

${ }^{5}$ Cf. Filip COUSSEEE et al., The emerging social pedagogical paradigm in UK child and youth care: Deus ex machina or walking the beaten path?, British Journal of Social Work, 40 (2008) 3, 789-805.

${ }^{6}$ Cf. Predrag HARAMIJA, Đuro NJAVRO, Tranzicija i njezini rezultati - zašto tranzicija iz komunističkog u demokratski sustav tržišnog gospodarstva nije ostvarila očekivanja [The 
sition and post-transition explain the confusion in the understanding of the environment especially on children. It can only assume the shock of some social structures, including family, brought about by the new capitalist environment in which private ownership and private initiative, free market and competition as prerequisites for fair starting positions had an advantage over the planned economy.7 Besides, we must not forget that in these countries' wars were fought between 1990 and 1995, in Bosnia and Herzegovina called the Bosnian War and in Croatia called the Croatian War of Independence. The former system was marked by a highly specific consumer culture that was defined as the socialist culture of shortage ${ }^{8}$ and the simultaneous fascination with the West.

This model is called self-managing socialism. Its ideological background was in the idea of associative work and the theory of alienation and had elements of Pierre Joseph Proudhon's works and anarchist learning. It appeared in the 1980s. The reason for this was the death of Yugoslavia's leader Josip Broz, but also the deep economic crisis in the country. In the historical-sociological context, self-managing socialism was carried out too quickly and according to the project - realization scheme as the model of self - managing socialism. In the social context, the working class, which was supposed to be the practical holder of such a system, was not the bearer of modern production because it was based on the ideas of the $19^{\text {th }}$ century. ${ }^{9}$ Thus, the political system did not do enough to teach the working-class self-managing socialism in a practical sense, and even more, studying its historical and social components was left out of the research.

However, from the very beginning, the communist authorities sought to encourage a major campaign of education and planned education of the population. This was especially true for the education of rural and working-class children, of course, in the spirit and ideology of the socialist revolution. For example, the children from the cities remained smaller compared to the children from the villages. The paradox of this meeting is witnessed by the adoption of the Law on Workers' Self-Government and Organization of Education in the spirit of self-governing socialism, the economic system of self-management and giving greater powers to local self-government, and by changing the financing of youth from state funds towards entrepreneurial finances. As a result, the number of students of economics, who were supposed to be the bearers of

Transition and its Results - Why the Transition from the Communist to the Democratic System of a Market Economy did not Meet Expectations], Obnovljeni Život, 71 (2016) 4, 515-527.

7 Cf. Katarina DADIĆ, Dijete u središtu konzumerizma [Child in the Middle of Consumerism], Medianali, 7 (2012) 14, 97-113.

${ }^{8}$ Cf. Breda LUTHAR, Homo ludens - Homo šoper. Uvod v potrošno kulturo [Homo ludens Homo shopper. Introduction to Consumer Culture], u: Aleš DEBELJAK et al. (ur.), Cooltura: Uvod v kolturne študije, Ljubljana, Študentska založba, 2002, 245-263.

9 Josip ŽUPANOV, Samoupravni socijalizam. Konac jedne utopije [Self-Managing Socialism: The End of a Utopia], Politička misao, 26 (1989) 4, 21-36, 32. 
the new socialist society, was sharply reduced, thus turning the political and educational system against itself and stigmatizing the children who chose such professions. The socialist system set up dormitories for children who did not have enough money for housing. They copied the tradition of Catholic boarding schools and convicts, but, under state control and in the spirit of socialism. However, due to the overcapacity of the dormitories, instead of functioning as educational institutions, they were transformed into »asylums for the feeding and lodging of children «. This completely lost the basic idea of creating a »new socialist man « in a practical sense, while the theoretical sense was not lacking. Therefore, it is possible to get the impression that the very system that allowed entrepreneurial financing of children's education actually exploited children in a way that they were a cheap labour force.${ }^{10}$ Certainly, the best example of creating a new socialist man from children (from early age/from elementary school) was founding of the so-called »pioneers«. These are children between the ages of seven and fourteen who were to be brought up and trained in the spirit of socialist consciousness, to work in self-governing order, and especially to develop fraternity and unity and internationalism. In doing so, the »pioneers« became the implementation of self-governing socialism that offered no alternative to children. ${ }^{11}$ As has already been said, the political and educational systems have given particular attention to physical and manual work. With children and young people, this has been manifested through so-called »work actions«. Their purpose was twofold: children were an inexpensive source of labour for the construction of infrastructure, and the system served them with an official communist ideology through the propaganda of engaging in »work actions «. ${ }^{12}$

This was the result of modest consumption in the socialist system that was in line with the ideology of the system itself which recognized only the usefulness of a certain product. The offer determined the needs and the ways of their satisfaction, and everything was directed towards suppressing any wishes, ${ }^{13}$ which completely aroused with the new economic and social system which

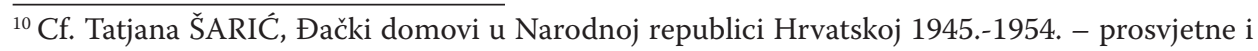
odgojne ustanove ili »azili za prehranu i noćenje«? [Pupil's Dorms in the People's Republic of Croatia from 1945 to 1954 - Educational Institutions or »Food and Bed Asylums«?], Časopis za suvremenu povijest, 45 (2013) 3, 441-459.

${ }^{11}$ Cf. Igor DUDA, Djeca socijalističke domovine. Izgrađivanje pionirske tradicije u Hrvatskoj 1950-ih godina [Children of the Socialist Homeland. Creation of the Pioneer Tradition in Croatia in the 1950s], u: Lada DURAKOVIĆ, Andrea MATOŠEVIĆ (ur.), Socijalizam na klupi. Jugoslavensko društvo očima nove postjugoslavenske humanistike, Pula - Zagreb, Sveučilište Jurja Dobrile Pula, Srednja Europa, 2013, 75-101.

${ }^{12}$ Cf. Reana SENJKOVIĆ, Svaki dan pobjeda. Kultura omladinskih radnih akcija [Every Day Winning. Culture of Youth Work Actions], Zagreb, Institut za etnologiju i folkloristiku, Srednja Europa, 2018.

${ }^{13}$ Cf. Sanja STANIĆ, Antonela BAKIĆ, Djeca u okruženju potrošačkog društva [Children in the Surrounding of the Consumer Society], u: Medina Vantić-Tanjić (ur.), Unapredenje kvaliteta života djece i mladih, Tuzla, Udruženje za podršku i kreativni razvoj djece i mladih, 2011, 143154. 
was visible in the mid-1990s when, in the two researched countries, society transferred from the »culture of shortage « to the »culture of abundance». This was marked by a completely new socioeconomic system - capitalism, as one of the major institutional dimensions of modernity. Similarly, transition and post-transition processes on consumption have caused several manifestations such as irrational spending that can be considered as a certain form of social deviation, then the tendency for self-expression, snobbery, uncontrollable consumption and/or concealment of actual social status through various forms of conspicuous consumption. These processes and values they carry have certainly contributed to the »liberation « of consumption and are continuously reproduced and transformed because of an interaction between actors and structures. It is precisely this context that authors define as a consumer society whose structural elements enable the stimulation of consumption which is represented as social action. Since consumer society and consumer culture are not separate or autonomous, it follows that consumer culture and its influence on societies and individuals is based on the fact that assigning ever greater significance to consumption is simultaneously accompanied by the general reorganization of symbolic production, everyday experience and practice ${ }^{14}$ which directly reflects on children themselves; this proves that consumer culture remains a term that also marks the modern perspective of values. These two terms ultimately create the consumer environment which is an expression of social, but also economic and media interaction between consumer society and consumer culture. It brings several consumer manifestations in relation to child such as commercialization ${ }^{15}$ consumerism $^{16}$, commodification ${ }^{17}$ and hyper-commodification ${ }^{18}$.

The educational problem in raising a child generated when the process of commercialization involves a child or a culturally specific category such as childhood, suggesting that a "pedagogical alarm«, to protect children and childhood, must urgently be triggered. The process of commodification oc-

\footnotetext{
${ }^{14}$ Cf. Mike FEATHERSTONE, Consumer Culture and Postmodernism, London, Sage, 1991.

${ }^{15} \mathrm{Cf}$. Scott LASH et al., Global Culture Industry: The Mediation of Things, Cambridge, Pility Press, 2007; Gordon MARSHALL, Dictionary of Sociology, Oxford, University Press, 1998.

${ }^{16} \mathrm{Cf}$. Margit KELLER, Veronika KALMUS, Between consumerism and protectionism: attitudes towards children, consumption and the media in Estonia, Childhood, 16 (2009) 3, 355-375; Peter N. STEARNS, Stages of consumerism: recent work on the issues of periodization, The Journal of Modern History, 69 (1997) 1, 102-117; Patti M. VALKENBURG, Media and youth consumerism, Journal of Adolescent Health, 27 (2000) 2, 52-56.

${ }^{17} \mathrm{Cf}$. Daniel T. COOK, The missing child in consumption theory, Journal of Consumer Culture, 8 (2008) 2, 219-243; Janet WASKO, The commodification of youth culture, u: Kirsten DROTNER, Sonia LIVINGSTONE (ur.), International handbook of children, media and culture, London, Sage, 2008, 460-474.

${ }^{18}$ Cf. Ramón LLOPIS-GOIG, Detraditionalization, Hyper-consumption and Ambivalence, u: Ramón LLOPIS-GOIG (ur.), Spanish Football and Social Change, London, Palgrave Macmillan UK, 2015; Angharad N. VALDIVIA, Living in a hybrid material world: girls, ethnicity and mediated doll products, Girlhood Studies, 2 (2009) 1, 73-93.
} 
curs simultaneously with the process of postmodernization and the process of hyper-commodification which signifies that all areas of child's life become "goods «, including family activities, feelings ${ }^{19}$, relationships ${ }^{20}$, even the person itself $^{21}$, etc. The commodification process began with the assignment of market value to material goods and ended with the commodification of the child and childhood in a way that every activity became a $»$ paid experience ${ }^{22}$ All the above leads us to consumer culture theory which is the study of consumption choices and behaviours from a social and cultural point of view, as opposed to economic or psychological perspective. It does not offer a grand unifying theory but refers to a family of theoretical perspectives that address the dynamic relationships between consumer actions, the marketplace and cultural meanings. ${ }^{23}$ Child and childhood are observed within the wider context of social transformation, which transforms the child into an individual, legitimate and selfsufficient consumer with an excluded authoritarian pattern. ${ }^{24}$ Consequently, contemporary childhood and consumer environment (consumer society and consumer culture) have no separate autonomy. It follows that the pedagogical point of view is only possible if modern childhood is observed and understood as a childhood composed of heterogeneous elements of society and culture.

»Fresh money and new information are two central motives of modern social dynamics $\ll{ }^{25}$ Gamson and associates emphasises media images as subtle forms which authors use to construct meanings of political and social issues. Although, the whole process seems natural to us and the social construction remains »invisible«, these images are not neutral but are the reflection of power and views of political and economic elites. Such images often belong to the undisputed area of media discourse and appear as transparent descriptions of reality, not as interpretations, and seem deprived of political implications. Examples of images from the undisputable area are the images of vulnerability and »angelic character « of children as well as of »wild adolescents « who need social control and protection. With the help of images, the media create different constructions of children which pedagogy needs to identify in order to gain insight into the mechanisms of creation of public opinion about children. ${ }^{26}$

\footnotetext{
${ }^{19} \mathrm{Cf}$. Arlie R. HOCHSCHILD, the managed heart: Commercialization of human feeling. Berkeley, Los Angeles, London, University of California Press, 2012.

${ }^{20}$ Cf. Steven MILES, Consumerism: as a Way of life, London, Sage, 2006.

${ }^{21}$ Cf. Charles W. MILLS, Bijeli ovratnik. Američke srednje klase [White Collar: the American Middle Classes], Zagreb, Naprijed, 1979.

${ }^{22}$ Cf. Jeremy RIFKIN, Doba pristupa [The Age of Access], Zagreb, Bulaja, 2005.

${ }^{23}$ Cf. Eric J. ARNOULD, Craig J. THOMPSON, Consumer culture theory (CCT): Twenty years of research, Journal of consumer research, 31 (2005) 4, 868-882.

${ }^{24} \mathrm{Cf}$. Daniel T. COOK, The missing child in consumption theory, Journal of Consumer Culture, 8 (2008) 2, 219-243.

${ }^{25}$ Niklas LUHMANN, The Reality of the Mass Media, Stanford, Stanford University Press, 2000, 21.

${ }^{26}$ Cf. William A. GAMSON et al., Media Images and the Social Construction of Reality, Annual Review of Sociology, 18 (1992) 373-393.
} 


\section{Stigmatisation of Children and Childhood}

The term »stigma« dates to ancient Greece where slaves were tattooed using a pointed instrument or had signs imprinted on their skin using glowing metal. ${ }^{27}$ Such a sign was called a stigma, and soon its function had grown from a mere sign of ownership to a sign that revealed something unusual or bad about the moral status of a person. Stigmatization is the process of global devaluation of an individual possessing a deviant attribute. That attribute is seen as the central aspect of the person's identity, while all his other attributes become irrelevant. ${ }^{28}$ Link and Phelan offer a widely influential definition of the stigma that they consider occurring when elements of labelling, stereotyping, separation, status loss and discrimination co-occur in a power situation that allows the components of stigma to unfold. ${ }^{29}$ Only by incorporating the component of power we can talk about stigmatization because it ultimately completely depends on the access to social, economic and political power which allows the identification of differences, the construction of stereotypes, the separation of labelled persons into distinct categories and the full implementation of exclusion and discrimination. However, the role of power in stigmatization is often overlooked, as in many cases differences in power are taken as given, to such an extent that they even seem natural. Such is, for example, a difference in power between adults and children. This is what Michael Foucault calls the »regime of truth «. ${ }^{30}$ This concept links the notion of truth to the explicitly political notion of regime. In the case of this paper, this is about the changes during the 1980s and 1990s in Croatia and Bosnia and Herzegovina when Yugoslavia falls, the war begins and the economic transition from socialist self-management to capitalist democracy occurs.

Gerbner and associates indicates that social groups that have the least power and influence are less present in the media than which contributes to the maintaining of their low social status. Members of these groups are called $» m i-$ norities « and, among others, they include women, elderly people, persons with special needs and children. Children, like other »minority « groups, represent a certain unknown area in the public eye, and when something is unknown it is easiest to turn to superficiality and stereotypes. ${ }^{31}$ The invisibility of children in

\footnotetext{
${ }^{27}$ Cf. Gerhard FAKL, Stigma: How We Treat Outsiders, New York, Prometheus Books, 2001.

${ }^{28} \mathrm{Cf}$. Erving GOFFMAN, Stigma. Notes on the Management of Spoiled Identity, New York, Jason Aronson, 1974.

${ }^{29}$ Falk, Stigma ..., 377.

${ }^{30}$ Michael FOUCAULT, Discipline E Punish. The Birth of the Prison, New York, Vintage Books, 1975, 23, 30.

${ }^{31}$ Cf. George GERBNER et al., Profiling Television Violence, u: Kaarle NORDENSTRENG, Michael S. GRIFFIN (ur.), International Media Monitoring, Cresskill, Hampton Press, 1999, 335365 .
} 
the media is present in several other analysis of media content. ${ }^{32}$ Children are also rarely asked for opinions or allowed to be protagonists, to comment and make statements which confirm that they are represented in a certain light and not in the way they perceive themselves. ${ }^{33}$

In previous research of Serbian, Croatian and Bosnian and Herzegovinian media children are constructed dominantly passive ${ }^{34}$ and that construction can be connected to Goffman's physical stigma which is, when it comes to children, related to their youthfulness and physical inability and those characteristics are at the root of constructs of »endangered child « and »child as an object of protection «. Media mostly write about children in the context of accidents or criminal activities committed against children. ${ }^{35}$ International analysis of media content have also shown that children are mostly represented as victims of accidents, violence, ill-treatment, illness, their problems are sensationalized and they are also used to entertain the audience as well as to encourage them to consumption..$^{36}$ The construct of the passive child, besides conditioning and producing inadequate social relationships towards children, may encourage children to identify or compare with the behavioural models presented. ${ }^{37}$

Construct of the active child is much less present and mostly refers to children who have fun and play carelessly, but who have no initiative and are not actual, autonomous participants in the life of their community. Images of children as actors in their education, successful and able to take responsibility or to make decisions in accordance to their age are almost completely absent

${ }^{32} \mathrm{Cf}$. Antura GOONASEKERA, Children in the News: reporting of children's issues in television and the press in Asia, Singapore, Asian Media Communication and Information Centre, 2001; Nada KORAĆ, Jelena VRANJEŠEVIĆ, Nevidljivo dete - slika deteta u medijima [Invisible Child - A Picture of a Child in the Media], Beograd, Jugoslavenski centar za prava deteta, 2001; Dale KUNKEL, Stacy L. SMITH, The News Media's Picture of Children in the United States, u: Celia von FEILITZEN, Ulla CARLSON (ur.), Children and Media. Image, Education, Participation, Göteborg, The UNESCO International Clearinghouse on Children and Violence on the Screen, 1999, 79-86.

${ }^{33}$ Lana CIBOCI et al., Djeca u dnevnim novinama. Analiza izvještavanja o djeci u 2010. [Children in the Daily Newspapers: Analysis of Reports on Children in 2010], u: Lana CIBOCI, Igor KANIŽAJ, Danijel LABAŠ (ur.), Djeca medija. Od marginalizacije do senzacije, Zagreb, Matica hrvatska, 2011, 103-167.

${ }^{34}$ Cf. Ines PERIĆ, Stigmatizacija djece u tiskanim medijima u Hrvatskoj i Bosni i Hercegovini [Stigmatization of Children in the Print Media in Croatia and Bosnia and Herzegovina] (PhD thesis), Osijek, Filozofski fakultet, 2018.

${ }^{35}$ Cf. Marta VLAINIĆ, Kako hrvatske dnevne novine izvještavaju o djeci: analiza sadržaja Jutarnjeg i Večernjeg lista [How do Croatian Daily Newspapers Report about Children: Content Analysis of Jutarnji list and Večernji list], Medijska istraživanja, 18 (2012) 1, 33-59.

${ }^{36} \mathrm{Cf}$. Marjory EBBECK, Sheela WARRIER, Image of the Singapore Child, Early Childhood Education Journal, 36 (2008) 83, 247-251; Saurav K. Shreshta, Print Media Coverage on Children's Issues, Kupondol, Hatemalo Sanchar, 2003.

${ }^{37}$ N. N., Izvješće o radu pravobranitelja za djecu za 2007. Godinu [Report on the Work of the Ombudsman for Children for 2007] (06.03.2008) https://www.udomiteljizadjecu.hr/wp-content/uploads/documents/dokumenti/Izvjesce\%20pravobraniteljice\%20za\%20djecu_2007.pdf (18.11.2020). 
from the media. ${ }^{38}$ Accordingly, the construct of a »competent child « which is the result of new interdisciplinary research of child and childhood and predominantly present in pedagogical theory is virtually non-existent in media discourse. Considering the importance and role of the media in the formation of our conceptions and constructions of the world, it is clear that systematic pedagogical research of the presence and the constructs of children in the media is necessary.

The pedagogisation of the aforementioned has helped us to make a clearer picture of the stigmatised child, and to be able to talk about destigmatisation it is necessary to answer the question »Who is the child « - viewed through the eyes of a pedagogue and why it must be a value above the interests of the consumer environment or the media. That is why, for example, the initial pedagogical education is especially important to teachers. How can such a process in pedagogy as science be justified? Why is the stigmatised speech about child extremely problematic? Why does it represent a challenge to pedagogy and how can it be counteracted? To create a clear image of the child, the authors used the research method of pedagogic anthropology which is not in the service of fragmentation of human being but rather serves for the representation of its fullness and integrity; this is the cornerstone of the pedagogical image of the child, which authors set in this paper as a corrective for all stigmatizing attempts to treat children solely as market or media subjects or objects rather than as people who are holders of values in themselves and by themselves. Through the process of pedagogical anthropology, the authors confirm that the child is the greatest value, that it is the creature of freedom and dignity, which is particularly reflected in pedagogy through the principle of integrity. This is one of the most important principles in upbringing and is ultimately confirmed by the Convention on the Rights of the Child and the new understanding of the child in modern pedagogy that imposed new childhood paradigms. These paradigms are expressed through the new pedagogical image of a child. The authors have to use this image to fully understand the task and the goal of an educator because the educator is part of the scope of our study. This is smoothed out in the example: the task of a pedagogue who relies on the pedagogical image of a child is not in the accumulation and transfer of knowledge and skill but in the creation of social and natural conditions for realising, experimenting and developing its abilities. In this regard, the pedagogical image of a child can be a way of destigmatisation of all media appearances, but also those from the consumer environment that are intended to create a child as a craving, unrestrained consumer who is loyal for life and, preferably, uncontrolled by himself but guided by the media image of what is expected of him. It is important to

\footnotetext{
${ }^{38}$ Cf. Cristina PONTE, Mapping news on children in the mainstream press, European Societies, 9 (2007) 5, 735-754; Alexandra SPINU, Images of Children in Romanian Newspapers (MA thesis), Oslo, University of Oslo, 2012.
} 
bear in mind the pedagogical socialization of children, which must be based on the development of consumer roles, the competitiveness of children to spend, and, ultimately, the monitoring of child's behaviour accordingly. From all of the abovementioned pedagogical problems of the contemporary child the authors conclude that for the balance of relations between values and the child, not only a harmonious upbringing for values is needed, but also climate, both media and consumer, in which the talk about values and the world of values have to confirm a specific practice, that is, access to a life experience accessible to everyone and which every individual can reach.

\section{Conclusion}

From all the above, it can be concluded that the pedagogical image of a child must necessarily be opposed to limiting or determining child and childhood in the way that the consumer environment and the media do. It is necessary to emphasize the historical context that has caused such problems which was especially pointed out in the elaboration of the topic. Socialist ideology crucially influenced such events because most of today's parents, but also the closest ancestors of their children, were raised during this historic period. Within the totality of the starting points of a child's development, the research has shown upbringing in socialism did not allow the pluralism of opinions and ideas. In an under-implemented transition process, society suddenly began to inherit a »culture of fullness « over its previous »culture of scarcity«, which was dominant in the socialist era. It has been replaced by collectivism, which is not synonymous with pluralism. With the creation of modern democracies after the 1990s, great efforts had to be made in Croatia and Bosnia and Herzegovina to exclude such socialist learning from childrearing. An additional problem with this was the war conflict that was waged in the area during the breakup of Yugoslavia. However, the consequences will be apparent for some time, primarily due to generational certainty.

To achieve that, the need arises for pedagogical education of parents which is the response to the growing needs of contemporary childhood to improve skills and knowledge of parents about and in parenting. Such education, based by the analysed newspapers, works and literature, should develop responsible behaviour (towards oneself, others and surroundings), human values and human rights, recognize and create conditions for the successful fulfilment of children's (but also adults') needs, create an environment for the development of the potential of every individual etc. In addition to parents' pedagogical education, the consumer and media environment on contemporary childhood also requires support programs for parents which should be focused on the social context of parenting, increasing the social network of family support, as well as 
greater community cohesion in the fight against stress and isolation in carrying out parenting tasks with the goal of comprehensive family-focused action. However, the pedagogical principle of integrity in approach, pedagogical ethics and emphasizing the interests of children in the context of pedagogical questions and problems raised. The second target group are teachers who should be empowered, through their pre-service as well as in-service education, to implement new approaches and methods which are in line with the new pedagogical image of the child. Educators create educational settings as well as their relationships with children following their image of a child. Pedagogical image of the child must be implemented in their education because only with its adoption they will form their practice in a way that will change children's perception of themselves as well as society's expectations from them.

Lastly, the authors believe that stronger pressure must be put on the media because despite the existence of the code of ethics, ethical guidance and recommendations specifically designed to educate journalists about rules and recommendations in reporting about children, journalists rarely adhere to them. One of the solutions lies, as well as with teachers, in improving their pre-service as well as in-service education, but what might be even more effective are stricter sanctions and calls for accountability of those who ignore the code of ethics of their profession and neglect all guidance and recommendations they might have been familiar with but decide to "forget« because of the pressure of constant publishing of new information and commercial interests of their employers. The media reality of our society is something we should acknowledge, but we do not have to reconcile it with it.

In these pedagogues must play an active role and set up the criteria of the moral pedagogical activity, in terms of judging good and bad upbringing in process and outcome. This would create an ideal environment for a child because a child needs another person as a cultural and ethical model, who will be the representative of culture and morals and who also stands in relation to the world, to the other and oneself. 


\section{Katarina Dadić" \\ Razmatranje slike djeteta u povijesnome i društvenome kontekstu modernoga potrošačkoga društva u Hrvatskoj i Bosni i Hercegovini \\ Sažetak}

Autori su raščlanili rezultate pedagoških, povijesnih, socioloških i komunikoloških istraživanja koja obrađuju pedagošku destigmatizaciju djece ostvarenih u Hrvatskoj te Bosni i Hercegovini, gdje dosad nije bilo sličnih pluriperspektivnih radova, a literature o toj temi gotovo da i nema. Pedagoška destigmatizacija djece značajno je izazvana povijesnim kontekstom u kojem su se Hrvatska te Bosna i Hercegovina nalazile od sredine do kraja 20. stoljeća. Žarište rada je na teorijskim uporištima pedagoške destigmatizacije i na pedagoškim oblicima dječjega »oslobađanja«. Nakana je dosegnuti novo razumijevanje djeteta u suvremenoj pedagogiji kao subjekta destigmatizacije s posebnim naglaskom na povijest, medije i potrošačko okruženje.

Ključne riječi: djetinjstvo, mediji, pedagogizacija, potrošačko društvo, povijesni kontekst.

* Doc. dr. sc. Katarina Dadić, Sveučilište u Zagrebu, Fakultet hrvatskih studija, Borongajska cesta 83d, HR-10000 Zagreb; e-mail: kdadic@hrstud.hr.

**: Ružica Bešlić Grbešić, prof. kroat. i soc., dipl. bibl., Sveučilište u Zagrebu, Fakultet hrvatskih studija, Borongajska cesta 83d, HR-10000 Zagreb; e-mail: rgrbesic@hrstud.hr.

***: Vlatko Smiljanić, mag. educ. hist., Sveučilište u Zagrebu, Znanstveni zavod Fakulteta hrvatskih studija, Borongajska cesta 83i, HR-10000 Zagreb; e-mail: vsmiljanic@hrstud.hr. 